\title{
Portable X-ray Fluorescence (PXRF) Analysis of Total Metal(loid)s and Sequential Extraction of Bioavailable Arsenic in Agricultural Soils of Animas Watershed
}

\author{
Gaurav Jha (D) April L. Ulery · Kevin Lombard • \\ Dawn VanLeeuwen · Colby Brungard (D) \\ Biswanath Dari (D) Debjani Sihi 10
}

Received: 24 March 2021 / Accepted: 25 June 2021 / Published online: 13 July 2021

(C) The Author(s) 2021

\begin{abstract}
The Animas River provides irrigation water in northwestern New Mexico and the Navajo Nation. Concerns regarding the river water quality arose on August 5, 2015, when approximately 11.35 million liters of heavy metal contaminated water was accidentally released from the Gold King Mine into the Animas River. This study sought to determine the total concentrations of 7 heavy metal(loid)s (As, $\mathrm{Pb}$, and $\mathrm{Zn}$ as metals of concern and $\mathrm{Fe}, \mathrm{Mn}, \mathrm{Ca}$, and $\mathrm{Cu}$ as metals of interest) using portable X-ray fluorescence (PXRF) in two agricultural fields and compare these values to Environmental Protection Agency
\end{abstract}

G. Jha $(\bowtie) \cdot$ A. L. Ulery · K. Lombard · C. Brungard Department of Plant and Environmental Sciences, New Mexico State University, Las Cruces 88003, NM, USA e-mail: gjha@ucdavis.edu

\section{G. Jha}

Department of Land, Air and Water Resources, University of California, Davis, CA 95616, USA

\section{VanLeeuwen}

Department of Economics, Applied Statistics and International Business, New Mexico State University, Las Cruces 88003, NM, USA

B. Dari

Agricultural and Natural Resources, Cooperative Extension, North Carolina Agricultural and Technical State University, Greensboro, NC 27420, USA

D. Sihi

Department of Environmental Sciences, Emory University, Atlanta, GA 30322, USA
(EPA) regional screening levels (RSL). Total concentrations of 6 out of 7 metals were below the RSL; only As exceeded the soil screening value of $7.07 \mathrm{mg} \mathrm{kg}^{-1}$ at some locations in the agricultural fields. We also determined water-soluble (WS) and exchangeable fractions (Ex) of As that might be available for agricultural crop uptake using sequential extractions. The WS-As ranged from 0.014 to $0.074 \mathrm{mg} \mathrm{kg}^{-1}$ and Ex-As ranged from 0.135 to $0.248 \mathrm{mg} \mathrm{kg}^{-1}$ and thus were less than 1 and $3 \%$ of the total As concentration respectively (ranging from 5.62 to $14.79 \mathrm{mg} \mathrm{kg}^{-1}$ ) and not considered a threat for plant tissue accumulation. While the concentrations of As observed in the agricultural fields may have exceeded screening levels, the As was not apparently plant available and its risk to crops was determined to be low.

Keywords Metal(loid)s · Gold King Mine spill · Legacy mining · Sequential extraction · Portable $\mathrm{X}$-ray fluorescence

\section{Introduction}

On August 5, 2015, 11.35 million liters (3 million gallons) of acidic, metal-laden water was accidentally released into the Animas River from the Gold King Mine (GKM) near Silverton, CO. The mine had been abandoned since 1923, and water had been accumulating behind bulkheads placed in the tunnels that were meant to seal the workings (US EPA, 2016). 
The accidental "blowout" occurred while crews were attempting to drain ponded water near the entrance of the mine. In northwestern New Mexico and the Navajo Nation, water from the Animas River, which joins the San Juan River downstream, is the primary source of irrigation water for crops. The spill impacted the cultivation of crops all across the watershed when irrigation ditches were closed for several days while the contamination plume moved downstream. August falls approximately at mid-season for most crops grown in the region; thus, shutting off the water was a difficult decision as it threatened crop life and the livelihood of many subsistence farmers (Smeal et al., 2014). Some of the irrigation ditches in the Navajo Nation remained closed until the 2016 growing season. While contamination from this one event may not have reached agricultural fields behind the closed irrigation ditches, mining over the last 150 years and various accidents may have released metals into the watershed.

The number of abandoned mines on federal lands includes 10,956 in Colorado, 6,669 in New Mexico, 4,931 in Utah, and 990 in Arizona (Bureau of Land Management, 2016). Some of these mines began operation in the late 1800 s, with the establishment of the Bonita Peak Mining District that includes some of the largest mines within the Silverton caldera (Fullen, 2017; Goss, 2016) such as the Red and Bonita, Mogul, Sunnyside, and the Gold King Mine. The sulfide deposits extracted from these mines were composed of iron (pyrites), copper (chalcopyrites), lead, zinc, and arsenic (Luedke \& Burbank, 1999). Sulfide-mineral ores such as pyrite, $\mathrm{FeS}_{2}$, are reduced, but when exposed to oxygen, as mine tailings, they become oxidized and acidic (Rose \& Cravotta, 1998). When large volumes of acid mine drainage were quickly propelled into the Animas River, the relatively slow crystallization process required to form stable minerals did not occur and instead incipient amorphous iron phases were formed (US EPA, 2016). The contaminated sludge laden with $\mathrm{Fe}$ and $\mathrm{Mn}$ oxides or "yellowboy" was visible as yellowish staining and coloration of water and sediments (Fullen, 2017; Jha et al. 2021a) (Fig. 1) (US Department of Interior, 2015). Calcareous rocks and minerals buffer the Animas River, thereby giving it a moderately alkaline $\mathrm{pH}$ that neutralizes acidic drainage water and complexes the dissolved metals (Schemel \& Cox, 2005). Although not soluble, these metals may still be transported as suspended sediments with the river flow (Li et al., 2013).

The elements carried by the Animas and San Juan Rivers into open irrigation ditches and agricultural fields may undergo various chemical reactions in the soil matrix over time. Therefore, it is essential to determine the concentrations of total metal(loid)s in the soil in order to monitor the extent of contamination in the fields. Total elemental concentrations in soils and plants are characterized by acid digestion methods using nitric, hydrochloric, perchloric, sulfuric, and/or hydrofluoric acids (Bettinelli et al., 2000; Kalra, 1998). Laboratory procedures involve sample drying, grinding, sieving, dilution, and analysis using inductively coupled plasma (ICP) or other spectroscopic techniques. However, portable X-ray fluorescence (PXRF) allows in situ monitoring of metal
Fig. 1 a The yellowcolored contaminated water flowing in the Animas River near Farmington, NM, after the Gold King Mine spill in August 2015. b Iron staining in water and deposits was due to oxidation and dissolution of pyrites $\left(\mathrm{FeS}_{2}\right)$. c and $\mathbf{d}$ Contaminated sediment samples on the banks of the Animas River in August 2015 (pictures taken by Kevin Lombard)
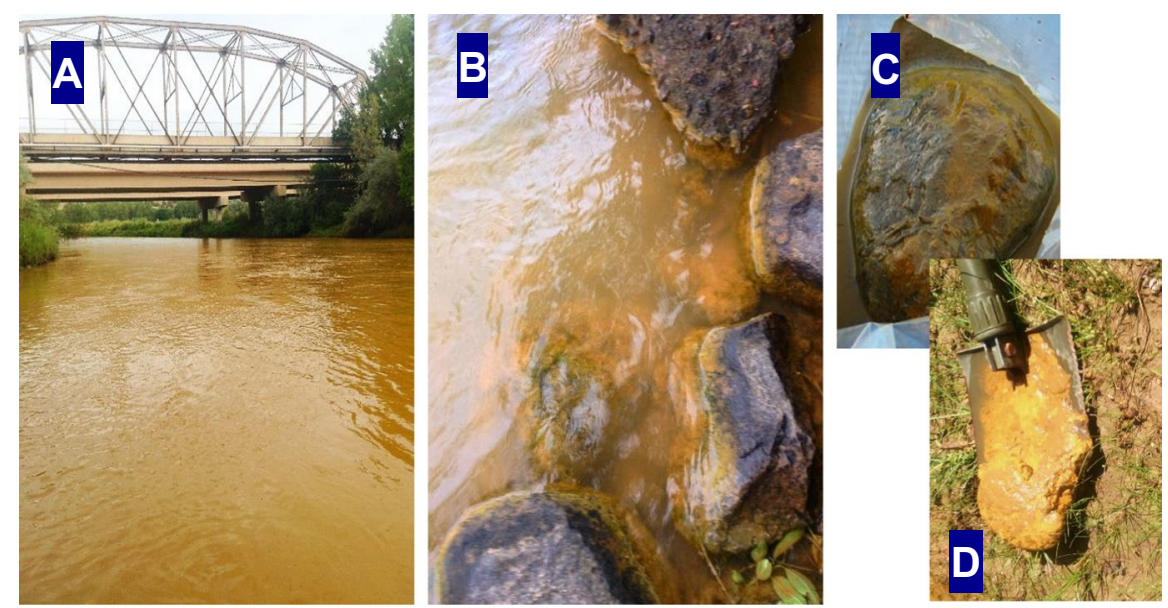
contaminants rapidly (Peinado et al., 2010; Shackley, 2012; Weindorf et al., 2013). PXRF can provide fast and accurate measurement of soil samples nondestructively and with little preparation (Weindorf et al., 2013). Al Maliki et al. (2017) performed a comparative study of lead $(\mathrm{Pb})$ determination from a smelter site in South Australia using ICP and PXRF and reported high correlation between the results obtained by the two methods. Chakraborty et al. (2017) identified the pollution hotspots in urban and peri-urban areas of Romania impacted by mining and smelter activities. They reported areas of arsenic (As) and $\mathrm{Pb}$ exceedances by interpolation kriging maps using the PXRF-acquired in situ field data. Therefore, PXRF is considered a robust and affordable technique to collect total metal concentration data from a high number of field locations that can help identify areas of high or low values for management purposes.

Large areas of the Animas River Watershed lie in the Navajo Nation, and the tribe uses soil and water not only for cultivation but also for ceremonial purposes. A large number of farmers in the watershed cultivate alfalfa (Medicago sativa) and cucurbitaceous vegetables using water from the irrigation ditch system. Thus, it is important to know the extent of metals and metalloids in the agricultural fields and whether they are toxic to plants and the environment. Metal(loid)s may be present in the soil in different forms or species that have varying toxicity or bioavailability. Determining total metal(loid) content in soils is most useful for regulatory purposes, but often the speciation of these metals is of more interest agriculturally to determine the biologically extractable or available forms (Zimmerman and Weindorf, 2010). Metals in soils are present both in solid phase and, to a lesser extent, the aqueous phase. In the solid phase, most metals are immobile, inert, and non-toxic as they are stabilized by surface complexation and precipitation mechanisms. However, in the aqueous phase, metals are mobile and may be toxic (Ogundiran \& Osibanjo, 2009) depending on other properties such as their oxidation state.

The theory behind sequential extraction is that the most mobile metals are removed in the first fraction and continue in the order of decreasing mobility and availability (Zimmerman and Weindorf, 2010). Water-soluble and exchangeable fractions significantly contribute to the bioavailable or plant available fractions. Thus, it is important to determine the concentrations of metals in these fractions as compared to the total concentrations that are used by regulatory agencies to evaluate soil, plant, and water contamination. Soil properties such as clay and organic matter content, $\mathrm{pH}$, redox, and elemental concentration all affect the solubility and bioavailability of metals but may not be accounted for by PXRF or other analytical methods that only measure total concentration.

The presence of minerals in soils contributes to the chemical interactions, solubility, and suspensions of metals in the soil matrix (Jha et al., 2021b). Manganese $(\mathrm{Mn})$ and iron $(\mathrm{Fe})$ oxides have a high adsorption affinity for metalloids like As that bind as inner-sphere mono- and bi-dentate surface complexes (Arcon et al., 2005). According to a study conducted in the Animas River Watershed by Rodriguez-Freire et al. (2016), the solubility of jarosite at near-neutral $\mathrm{pH}$ limits the remobilization of several metals in sediments. Arsenic sorption in soil is largely controlled by the content and nature of the iron oxides and hydroxides present (Alloway, 2012). Arsenate and arsenite form inner-sphere complexes with iron and aluminum oxide minerals using ligand exchange (Sparks, 2003). On calcite minerals and in calcareous soils, arsenic sorption operates through chemisorption, also described as inner-sphere complexation phenomenon (Alexandratos et al., 2007). In addition, As concentration may depend on organic matter content of the soil. Organo-arsenic complexes tend to reduce the bioavailable fractions of As (Kumar et al., 2021). Therefore, risk assessment of As is evaluated based on solubility and its transfer from soil to plant matrix (Mandal et al., 2019).

This study focused on determining the total concentration of 7 metal(loid)s that were considered elements of interest potentially contributed from abandoned mines in the region. These metal(loid) $s$ included arsenic (As), iron (Fe), manganese ( $\mathrm{Mn})$, lead $(\mathrm{Pb})$, zinc $(\mathrm{Zn})$, calcium $(\mathrm{Ca})$, and copper $(\mathrm{Cu})$. In this study, $\mathrm{As}, \mathrm{Pb}$, and $\mathrm{Zn}$ were identified as potential contaminants of concern, while the other metals ( $\mathrm{Fe}, \mathrm{Mn}, \mathrm{Ca}$, and $\mathrm{Cu}$ ) were chosen for study as metals of interest because they are generally found in high concentrations in acid mine drainage or due to their naturally high concentration in soils of this region. Metal(loid) concentrations that exceeded the RSL were mapped to determine their spatial variability in 
two fields. The water-soluble and exchangeable fractions of these metal(loid)s were determined from representative field samples to compare the plant available fraction and the total fraction. There is no other published study estimating the bioavailable fraction of As in field soils of Animas watershed. Therefore, this research is a valuable addition in environmental monitoring of soil contamination after a mine spill to help the consumers and growers of the region understand the presence and availability of metal(loid)s in agricultural field soils used for growing crops like alfalfa, corn (Zea Mays), and cucurbits.

\section{Materials and Methods}

\subsection{Site Description, Sample Size, and Features}

The study was conducted in agricultural fields irrigated by river water in the Animas River Watershed of New Mexico, USA. The Animas River flows from Colorado and enters into New Mexico where it joins the San Juan River in Farmington, NM, before entering the Navajo Nation, which extends to northwestern NM, southeastern Utah, and northeastern Arizona. The geologic setting of this region is a result of multiple episodes of hydrothermal activities that produced widespread areas of pyrite alterations and quartz-pyrite-metal veins (Church et al., 2007). Two fields irrigated by water from the Animas and San Juan Rivers, respectively, were selected to evaluate metal(loid) concentrations in January of 2017. One field was located in the upper region of the watershed and was irrigated by the Animas River water. The second field was located in the lower watershed area, irrigated by San Juan River water (Fig. 2). Alfalfa is grown on the field located in the Upper Animas area, and cucurbitaceous vegetables were grown on the field in the San Juan River area. These fields are designated as $\mathrm{A}$ and $\mathrm{V}$ throughout the discussions in this paper, respectively. These fields were at an elevation between 1400 and $1700 \mathrm{~m}$ above sea level. In order to keep the identity of landowners anonymous, the exact coordinates of these fields are not provided in this public report. In each field, 75 sampling points were scanned in situ using the PXRF and 7 random samples were collected from each field $(0-2 \mathrm{~cm})$ for laboratory analysis of soil properties and bioavailable fractions. The soil properties were measured by homogenizing the soil samples collected from each field. About $5 \mathrm{~g}$ of soil was taken from each of the 7 sampling bags from each field, A and V, and composited into one sample. Soil $\mathrm{pH}$, electrical conductivity, calcium $(\mathrm{Ca})$, magnesium $(\mathrm{Mg})$, and sodium $(\mathrm{Na})$ were measured in the saturation paste extract (Allison and Richards, 1954). The concentrations of $\mathrm{Na}, \mathrm{Ca}$, and $\mathrm{Mg}$ were used to calculate the sodium adsorption ratio. Soil organic matter was determined using the Walkley and Black titration method (Gavlak et al., 2003; Nelson \& Sommers, 1996). Nitrate-nitrogen was determined in a water extract (1:5, soil:water) using the Cadmium Reduction Column Method on a Technicon Autoanalyzer (Ludwick, 1974). Potassium (K) content was determined in a water extract (1:5) using inductively couple plasma spectroscopy (Cihacek, 1983). Extractable soil phosphorus (P) was analyzed using the Olsen bicarbonate method and a spectrophotometer to measure colorimetric samples (Olsen et al., 1954).

\subsection{Field Sampling}

Using a random sampling scheme, 150 points $(75$ points in each of 2 fields) were established using ArcGIS (ESRI, Redlands, CA, USA). These points were downloaded into an eTrex (Garmin, Olathe, KS, USA; geolocation accuracy $\sim 5 \mathrm{~m}$ ) handheld global positioning receiver. The in situ analysis of metal(loid) concentrations in the field was done using a Delta Premium 6000 portable X-ray fluorescence (PXRF) spectrometer (Olympus, Waltham, MA, USA) (Weindorf et al., 2014; Weindorf \& Chakraborty, 2016). The instrument was calibrated using a stainless-steel alloy chip prior to the field scanning. The PXRF instrument was operated in Soil Mode at $30 \mathrm{~s}$ per beam for three beams completing $90 \mathrm{~s}$ for each point scanned in the field. Any loose organic material, stones, pebbles, or any sharp object on the soil surface was scraped prior to the scan. The instrument was calibrated by reading a silica blank and National Institutes of Standards and Technology (NIST)-certified reference materials (e.g., NIST 2711a and NIST 2710a).

During the study, an additional 62 PXRF-scanned soil samples were collected separately from ten agricultural fields across the watershed from the surface $(0-2 \mathrm{~cm})$ of the agricultural fields using a stainless-steel trowel. The purpose of analyzing these 
Fig. 2 Location and fields of study designated as A for alfalfa and $\mathrm{V}$ for vegetable field irrigated by the Animas and San Juan Rivers

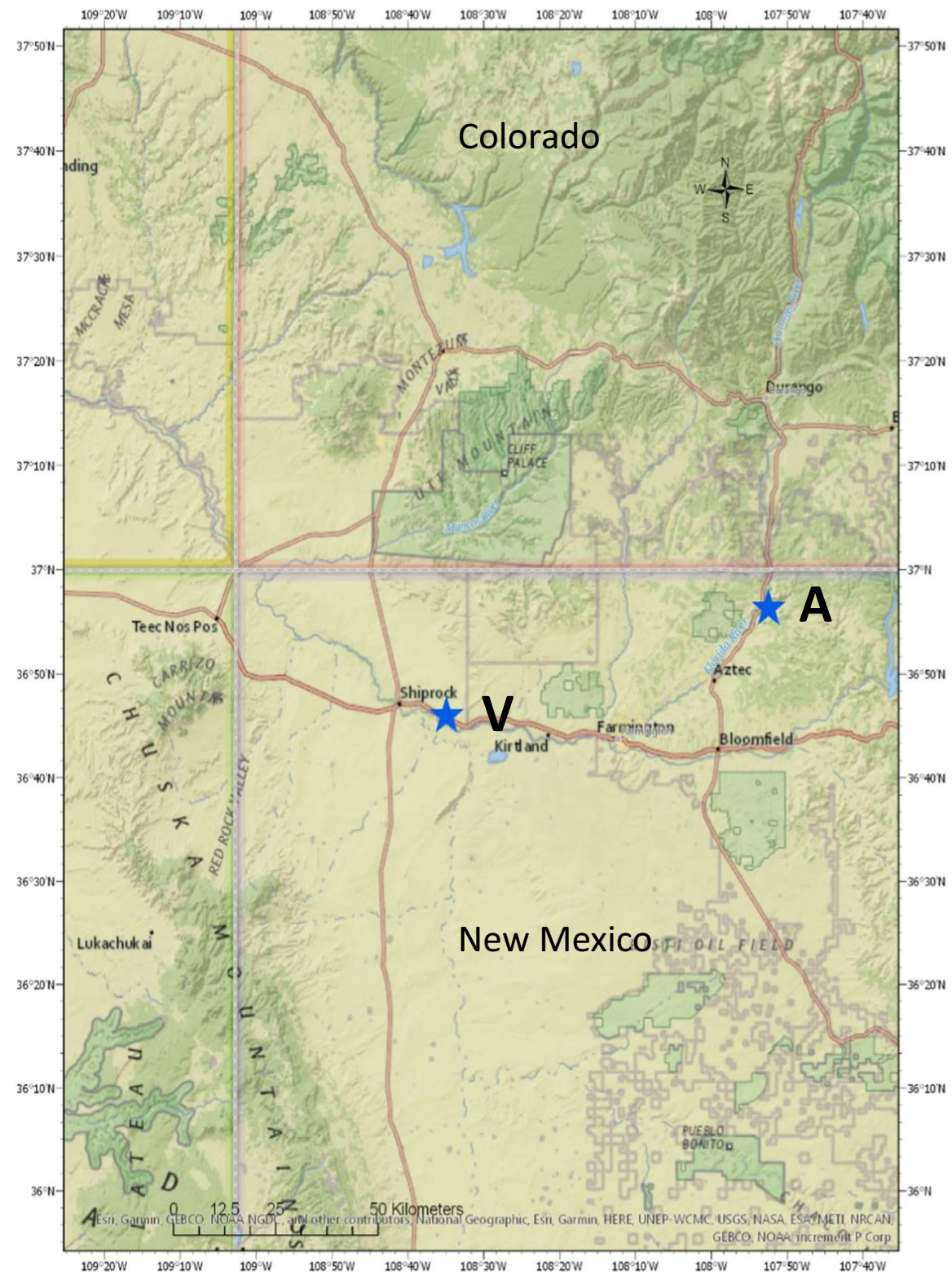

additional samples was to compare the PXRF results with laboratory analyses and validate the measurements collected under rapid, in situ conditions.

\subsection{Laboratory Analysis}

A laboratory study was conducted to determine the total concentration of metal(loid)s of interest and compare with PXRF results from the field and to determine the plant available fraction (assumed to be represented by water-soluble and exchangeable fractions) in soils using partial sequential extraction (Tessier et al., 1979).

Total metal concentrations of soil samples were determined using EPA Method 3051A (microwaveassisted acid digestion of sediments, sludges, soils, and oils). Briefly, $0.5 \mathrm{~g}$ of air-dried soil was mixed with $9 \mathrm{~mL}$ of concentrated nitric acid and $3 \mathrm{~mL}$ of concentrated hydrochloric acid within Teflon reaction vessels and digested using a Microwave Accelerated Reaction System at 90 bars of pressure and $200{ }^{\circ} \mathrm{C}$ temperature (US EPA, 2007). A quality 
control (NIST 2710a or 2711a) and blank were included in each batch of samples digested. All quality control samples fell within the acceptance range of the known value for total metal concentration as specified by the EPA. The certified reference concentrations for metal(loid)s and their recovery percentages for PXRF and ICP analysis are presented in Online Resource 1 as Supplementary table 1. Digested solutions were filtered through Whatman \#2 V filter paper, triple-rinsed with deionized (DI) water, then brought to $100 \mathrm{~mL}$ volume with DI water. Soil digests were analyzed for elements of interest (As, Fe, $\mathrm{Mn}, \mathrm{Pb}, \mathrm{Zn}, \mathrm{Ca}, \mathrm{Cu}$ ) using SW-846 Method 6010D Inductively Coupled Plasma (ICP) technology. Arsenic was analyzed using ICP-MS for better accuracy and detection of lower concentrations of As in samples. All metals except As were analyzed using an Optima 4300 Dual View Inductively Coupled Plasma-Atomic Emission Spectrometry (ICP-AES; Perkins-Elmer, Waltham, MA), also referred to as Inductively Coupled Plasma/Optical Emission Spectrometry (ICPOES). Total As was analyzed on a Perkin Elmer Elan DRC-e ICP-Mass Spectroscopy (ICP-MS; Perkin Elmer, Waltham, MA).

The metal(loid)s in excess of regulatory limits were identified and further analyzed using the initial steps of the sequential extraction procedure developed by Tessier et al. (1979) to determine the concentrations in the water-soluble and exchangeable fractions of the soil. Triplicate $2-\mathrm{g}$ soil samples were weighed into centrifuge tubes. Ten milliliters of DI water was added to the samples and the tubes were closed and shaken on a mechanical shaker for $1.5 \mathrm{~h}$. The soil and watersoluble fractions were separated by centrifuging at $6000 \mathrm{rpm}(12,000 \mathrm{~g}$ based on instrument diameter of $254 \mathrm{~mm}$ ) for $30 \mathrm{~min}$. The supernatant was decanted and analyzed for As using ICP-MS by following EPA Method 200.8. In the next step, $16 \mathrm{~mL}$ of $0.1 \mathrm{M}$ magnesium chloride ( $\mathrm{pH} 7.0)$ was added to the soil residue, shaken for $1.5 \mathrm{~h}$, and centrifuged at $6000 \mathrm{rpm}$ for $30 \mathrm{~min}$. The supernatant was analyzed as in the first step to provide the exchangeable fraction in the soil. Magnesium chloride interference on the ICP-MS required high dilutions as the undissolved or sedimented salt crystal in undiluted solution can block the nebulizer.

\subsection{Spatial and Statistical Analysis of Total Metal(loid) Concentration}

Spatial prediction was done by geostatistical analysis of total As distribution in two fields using Geostatistical Analyst and Spatial Analyst tools in ArcGIS 10.7.1 for those metals that exceeded the regional screening level (RSL). Spatial prediction maps were interpolated using ordinary kriging based on known values from PXRF scans. Spherical, circular, and exponential variogram models were fit to As concentrations in both fields and compared using the root mean square error (RMSE) derived from leave-one-out cross validation. A set of 75 sampling locations in each field is repeatedly split into a training set containing all but one observation, and a validation set that contains only that observation. The test error is then estimated by averaging the resulting mean squared errors. The first training set contains all but observation 1 , the second training set contains all but observation 2, and so forth (Webb et al., 2010). The model that returned the lowest RMSE was selected for each variable. The root mean square standardized error (RMSSE) was also considered for identifying the best fitted model. It is an indicator to determine the underestimation and overestimation of a model fit and should be close to 1 for the best fit model (Ohmer et al., 2017). Variogram parameters like nugget, partial sill (pSill), sill, range, and nugget to sill ratio were analyzed to interpret the strength of the fitted semivariogram model. Statistical analyses were done using SAS Version 9.4 software (SAS Institute, Cary, NC). Correlation function was performed to determine the strength of the relationship (correlation coefficient) between PXRF and lab-based analysis of metal(loid)s in validation samples $(n=62)$ collected from 10 agricultural fields in the Animas and San Juan Watershed. The validation of PXRF was necessary for samples collected across the watershed to increase the accuracy and reliability of the PXRF results as these correlations for rapid and in situ measurements are site specific.

\section{Results and Discussion}

\subsection{Soil Properties}

Soils in the two fields were classified as Fruitland sandy loam (Coarse-loamy, mixed, superactive, calcareous, mesic Typic Torriorthents) and Fruitland 
sandy clay loam (Coarse-loamy, mixed, superactive, calcareous, mesic Typic Torriorthents), respectively, for the alfalfa field irrigated by Animas River water and the vegetable field irrigated by San Juan River water. The composite soil $\mathrm{pH}$ in the alfalfa field was neutral (7.0) while $\mathrm{pH}$ in the vegetable field was slightly alkaline (8.1). These soil $\mathrm{pH}$ values lie in the range of 6.5 to 8.4 reported for New Mexico soils (Flynn, 2012). According to the interpretations of soil properties in New Mexico soils reported by Flynn (2012), organic matter was in the low (1.0-2.0\%) range for the alfalfa field and very low (less than $1 \%)$ in the vegetable field. Nitrate-nitrogen was in the medium (11-30 $\mathrm{mg} \mathrm{kg}^{-1}$ ) range for both fields. Phosphorus content was very high (>31 $\left.\mathrm{mg} \mathrm{kg}^{-1}\right)$ in the alfalfa field but very low $\left(<7 \mathrm{mg} \mathrm{kg}^{-1}\right)$ in the vegetable field. Potassium was in the medium (31-60 $\left.\mathrm{mg} \mathrm{kg}^{-1}\right)$ range for both fields.

\subsection{Validation of PXRF In Situ Field Scans vs. Laboratory Analysis}

PXRF is a rapid in situ analysis of metal contaminants. The samples analyzed in the laboratory using ICP instruments after acid digestion showed moderate to strong correlation with in situ field scanned PXRF metal concentration results. The correlation coefficients depicting the strength of linear relationships between the two methods used to analyze the samples are shown in Table 1. Calcium concentration measured by both methods shows the strongest correlation between PXRF and ICP measured concentration values with a coefficient of 0.96 , while the lowest coefficient was 0.80 for Mn (Table 1). According to Chan (2003), these coefficient values are considered "Very Strong" for correlation between two variables.

The strength of correlation obtained for validating PXRF results with ICP analyzed samples for the Animas River Watershed affirms the use of PXRF for in situ analysis of the 7 elements of interest in this study. Other researchers have reported higher correlations between ICP and PXRF measurements, but they had done more preparation of the samples including air drying, grinding, and sieving to a uniform particle size prior to PXRF scanning (Rouillon \& Taylor, 2016). Field scanning by PXRF is not as accurate, but still provides a robust, low-cost estimate of metal(loid) concentration and distribution (Weindorf et al., 2013). The sample results from PXRF were also within $20 \%$ of the NIST 2710a and 2711a standard concentration values, measured at the beginning and end of each field survey.

\subsection{Total Metal(loid) Concentrations in Agricultural Fields}

The descriptive statistics (mean, standard deviation, minimum and maximum) of heavy metal(loid) s analyzed using PXRF by scanning 150 points in two fields are shown in Table 2. The mean metal
Table 1 Validation of metal concentration data analyzed using PXRF and ICP ( $n=62$ points) across Animas River Watershed (5\% level of significance)

\begin{tabular}{lllllll}
\hline Element & Instrument & $\begin{array}{l}\text { Correlation } \\
\text { coefficient }\end{array}$ & $\begin{array}{l}\text { Mean } \\
\left(\mathrm{mg} \mathrm{kg}^{-1}\right)\end{array}$ & Standard deviation & $\begin{array}{l}\text { Minimum } \\
\left(\mathrm{mg} \mathrm{kg}^{-1}\right)\end{array}$ & $\begin{array}{l}\text { Maximum } \\
\left(\mathrm{mg} \mathrm{kg}^{-1}\right)\end{array}$ \\
\hline Arsenic & ICP-MS & 0.88 & 6.85 & 2.79 & 2.75 & 14.79 \\
& PXRF & & 6.33 & 2.50 & 2.70 & 13.00 \\
Iron & ICP-OES & 0.82 & 16,217 & 4694 & 7577 & 27,320 \\
& PXRF & & 17,816 & 5941 & 5585 & 32,683 \\
Manganese & ICP-OES & 0.81 & 394.69 & 139.90 & 135 & 746 \\
& PXRF & & 429.94 & 167.70 & 132 & 1005 \\
Lead & ICP-OES & 0.90 & 46.45 & 26.36 & 6.23 & 124.8 \\
& PXRF & & 43.57 & 25.44 & 7.90 & 121.0 \\
Zinc & ICP-OES & 0.82 & 107.99 & 52.50 & 30.84 & 323.7 \\
& PXRF & & 107.11 & 57.88 & 36.90 & 401.0 \\
Calcium & ICP-OES & 0.96 & 10,787 & 8553 & 2198 & 37,770 \\
& PXRF & & 12,097 & 10,218 & 2110 & 45,330 \\
Copper & ICP-OES & 0.81 & 21.74 & 8.12 & 8.52 & 51.01 \\
& PXRF & & 23.18 & 9.50 & 8.30 & 65.00 \\
\hline
\end{tabular}


concentrations $\left(\mathrm{mg} \mathrm{kg}^{-1}\right)$ of respective metal(loid) $\mathrm{s}$ of interest in the two fields combined ranked, from highest to lowest, $\mathrm{Ca}>\mathrm{Fe}>\mathrm{Mn}>\mathrm{Zn}>\mathrm{Pb}>\mathrm{Cu}>\mathrm{A}$ $\mathrm{s}$. The soils in the two fields appear to be calcareous, meaning that they contain calcium carbonate (and effervesce, or "fizz" when acid is added). The average concentration of $\mathrm{Ca}$ in the vegetable field irrigated with San Juan River water is sevenfold higher than the alfalfa field irrigated by Animas River water. This may be attributed to the location of the vegetable field further downstream that tends to accumulate higher amounts of calcium carbonate that come along with the river water. As soils erode into the rivers or irrigation channels, they release some Ca (Briggs \& Ficke, 1977). The Animas River is buffered by calcium carbonate and maintains a slightly alkaline $\mathrm{pH}$ between the Upper Animas and conjunction with the San Juan River. The moderately alkaline, well-buffered $\mathrm{pH}$ suppresses the dissolved metals in the Animas River and its water discharging into the San Juan River (Schemel \& Cox, 2005). The analytical results presented in Online Resource 1 as Supplementary table 2 show the metal(loid) concentrations in the irrigation water. The concentrations of metal(loid)s in irrigation water were below the EPA guideline value for drinking water and were considered safe for irrigating the agricultural crops of the Animas watershed.

Historically, geologists in other studies have also reported high concentrations of $\mathrm{Fe}$ and $\mathrm{Mn}$ in the region's lithology. Iron-rich groundwater deposits have infiltrated after pyritic weathering (Wirt et al., 2007; Yager \& Bove, 2007; Yager et al., 2003) through the mineral deposits with polymetallic base (copper-lead-zinc and copper-arsenic-antimony) predominant in the Silverton and San Juan calderas that adjoin the Animas River Watershed (Casadevall \& Ohmoto, 1977; Varnes, 1963). According to Church et al. (2007), the geologic alterations of quartz-sericite-pyrite deposits have substantially contributed to the loads of $\mathrm{Mn}$ and $\mathrm{Zn}$ across the watershed. These metal loads moved downstream with the flow of river water. The mean values of PXRF scanned metal(loid) concentrations for $\mathrm{Mn}$ and $\mathrm{Zn}$ in the two fields were below the EPA or the New Mexico Environment Department (NMED) residential soil screening level (RSSL) values. However, on monitoring the range for other metal(loid)s, the maximum value for As exceeded the NMED RSSL of $7.07 \mathrm{mg} \mathrm{kg}^{-1}$. These areas of exceedance indicate the presence of at least one or more sampling location(s) where the As concentrations are above the RSSL value. These findings are similar to the observations reported in the study on three agricultural fields in the Upper Animas Watershed where As exceeded at certain locations in the fields for all three growing seasons (Jha et al., 2021a).

\subsection{Spatial Distribution of Total Arsenic in Agricultural Fields}

Arsenic distribution in the studied fields was characterized using spatial analysis of total arsenic (mg

Table 2 Descriptive statistics (mean, standard deviation (SD), minimum and maximum concentrations) of metal concentration (in $\mathrm{mg} \mathrm{kg}^{-1}$ ) in alfalfa field (A) and vegetable field (V) scanned at 75 points per field using PXRF

\begin{tabular}{|c|c|c|c|c|c|c|c|c|}
\hline Field & & $\begin{array}{l}\mathrm{Ca} \\
\left(\mathrm{mg} \mathrm{kg}^{-1}\right)\end{array}$ & $\mathrm{Mn}$ & $\mathrm{Fe}$ & $\mathrm{Cu}$ & $\mathrm{Zn}$ & As & $\mathrm{Pb}$ \\
\hline & RSSL* & N/A & 1800 & 55,000 & 3100 & 23,000 & $7.07 * *$ & 400 \\
\hline \multirow[t]{4}{*}{ A } & Mean & 5399 & 313.65 & 15,886 & 14.10 & 56.51 & 4.09 & 24.79 \\
\hline & SD & 2259 & 65.64 & 2724 & 3.70 & 14.92 & 1.30 & 9.90 \\
\hline & Min & 3317 & 218.00 & 11,058 & 7.00 & 25.60 & 2.50 & 12.40 \\
\hline & Max & 18,049 & 569.00 & 27,721 & 27.80 & 106.00 & 8.60 & 59.70 \\
\hline \multirow[t]{4}{*}{ V } & Mean & 36,926 & 305.00 & 21,824 & 20.63 & 70.09 & 7.36 & 17.04 \\
\hline & SD & 6602 & 50.19 & 3809 & 3.75 & 9.73 & 1.51 & 3.10 \\
\hline & Min & 23,106 & 162.00 & 9468 & 11.00 & 46.00 & 4.70 & 9.00 \\
\hline & Max & 59,583 & 412.00 & 27,245 & 28.00 & 99.00 & 11.3 & 25.00 \\
\hline
\end{tabular}

* RSSl, residential soil screening level (US Environmental Protection Agency recommendations except Arsenic); **As per New Mexico Environment Department (2017). 
$\mathrm{kg}^{-1}$ ). The spatial maps developed by ordinary kriging interpolation technique using known concentration values of As at 75 points scanned using PXRF are shown in Fig. 3(a) and (b) for the two fields irrigated using Animas and San Juan River waters respectively. The kriging maps are spatial interpolation using weighted average of metal(loid) concentrations to estimate the concentrations at unsampled locations. The weighted averages are derived from the semivariogram model that quantifies the changes with increasing distance between sampling locations (Cambardella et al., 1994). Figure 3a represents the spatial distribution of As in the field irrigated by Animas River under pivot irrigation. The vegetable field (Fig. 3b) demonstrates the distribution of As in field irrigated by San Juan River water under furrow irrigation with water entering the field from the northeast direction and moving towards the southwest direction. The two fields were under different irrigation managements, and had different soil properties, locations, and cropping systems. However, the distribution maps indicate the accumulation of As in regions of lower elevations in both fields. In the vegetable field, the furrow irrigation system may tend to mobilize As towards the rear end of the field or away from the irrigation water inlet or source. The locations of high As concentrations were not evenly spread in the fields, but found in specific regions in the two fields. Additionally, the amount of exceedance over the RSSL (7.07 $\mathrm{mg} \mathrm{kg}^{-1}$ ) was different in each field with the As concentrations in the alfalfa field ranging only up to $8.6 \mathrm{mg} \mathrm{kg}^{-1}$ but in the vegetable field, the maximum As value was in excess of $11 \mathrm{mg} \mathrm{kg}^{-1}$. Semivariogram parameters for the geostatistical modeling of As are presented in Table 3. The reliability of spatial maps is affected by several factors including sampling density, distribution, and variability in data (Li \& Heap, 2011). Therefore, cross validation is an important step to assess the accuracy of the interpolation. In cross validation, each measured data point is sequentially omitted and the value is predicted using the rest of the data (Ohmer et al., 2017). The RMSE is a measure of model performance. The lower the value of RMSE, the better the model fit (Xiaopeng et al., 2012). Therefore, the model that gave the lowest RMSE value was considered to be the optimal model for the semivariogram. The RMSE value for field A is larger than the RMSE value of field V, which is likely due to lower variability in As concentration in field $\mathrm{V}$ than field $\mathrm{A}$. Both fields had an RMSSE close to 1 , indicating that there was no overestimation or underestimation of predicted values based on known values of total As concentrations at scanned PXRF points. The semivariogram ranges are an indicator of
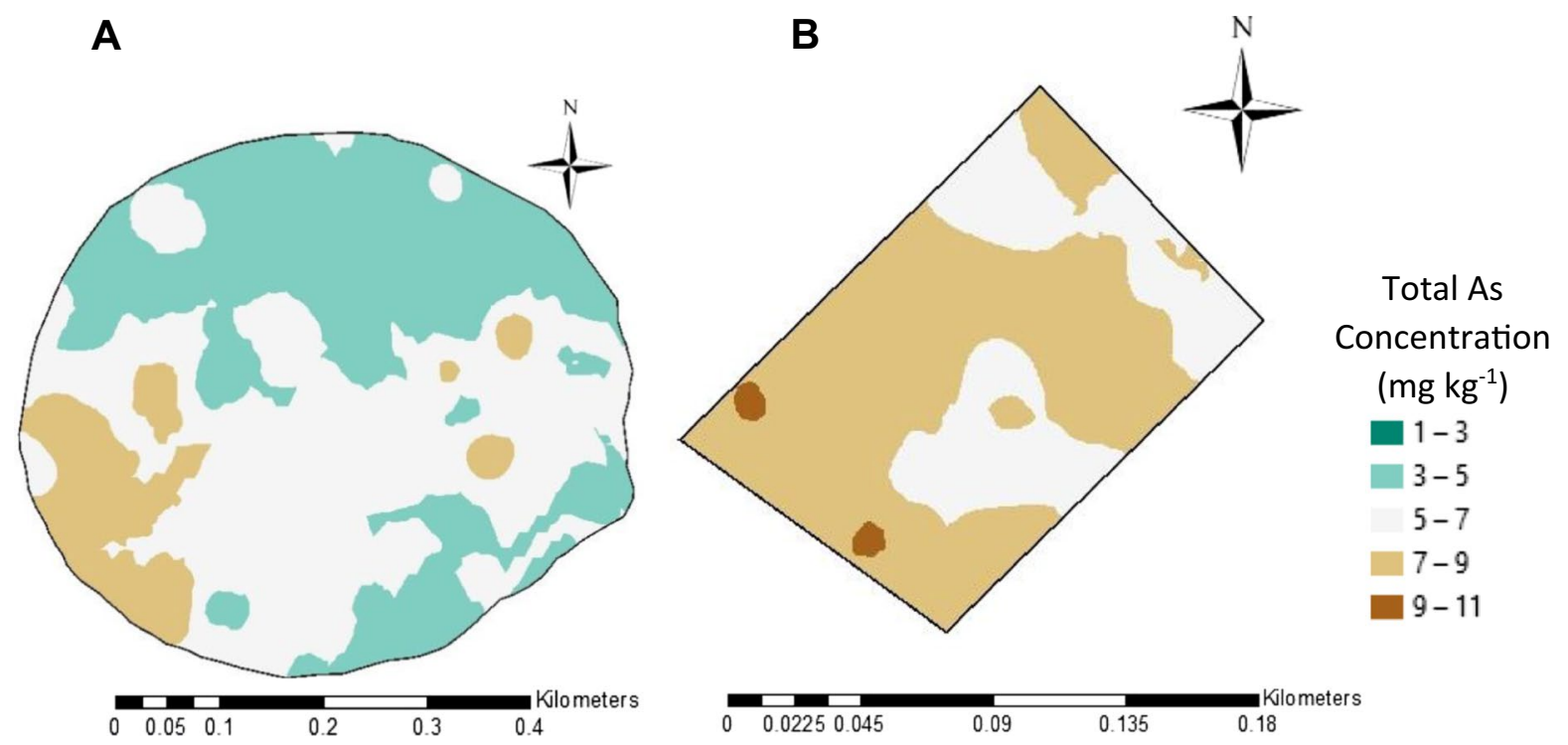

Fig. 3 Spatial distribution of As (in $\mathrm{mg} \mathrm{kg}^{-1}$ ) in agricultural fields irrigated by (a) Animas and (b) San Juan River waters respectively 
Table 3 Variogram parameters for geostatistical mapping

\begin{tabular}{|c|c|c|c|c|c|c|c|c|}
\hline Field & $\begin{array}{l}\text { Number of PXRF } \\
\text { sampling points }\end{array}$ & Model & RMSE* & RMSSE** & Range & Nugget & Sill & $\begin{array}{l}\text { Nugget } \\
\text { to sill } \\
\text { ratio }\end{array}$ \\
\hline A & 75 & Circular & 0.154 & 1.01 & 6.4 & 0.094 & 0.257 & 0.36 \\
\hline V & 75 & Exponential & 0.149 & 0.99 & 5.0 & 0.065 & 0.255 & 0.25 \\
\hline
\end{tabular}

*Root mean square error.

**Root mean square standardized error.

RMSE, range, nugget, and sill are reported in meters.

the strength of autocorrelation and indicate stronger spatial correlation for samples separated by distances shorter than the range values (Cambardella et al., 1994). The variogram range of total As in field A was $6.4 \mathrm{~m}$ and in field $\mathrm{V}$ was $5 \mathrm{~m}$. The spatial correlation increases with an increase in the number of sampling points or sampling density (Kabir et al., 2016). Therefore, according to the spatial range, a PXRF scanning distance of less than $6.4 \mathrm{~m}$ for field $\mathrm{A}$ and less than $5 \mathrm{~m}$ in field $\mathrm{V}$ would give stronger spatial correlation and lower prediction error. Nugget is the semivariance at separation distance equal to zero and is an indicator of variability that is undetectable at the resolution of mapping (Cambardella et al., 1994). The nugget to sill ratio is an indicator of the strength and reliability of predictions in spatial variability map (Cambardella et al., 1994). Small nugget to sill ratios indicate strong spatial dependency while a ratio of 1 indicates no dependency (Allan, 2018). Therefore, field A has comparatively moderate spatial dependency (nugget to sill ratio $=0.36$ ) and field $\mathrm{V}$ shows strong spatial dependence (nugget to sill ratio $=0.25$ ) between sampling locations.

\subsection{Bioavailable Fractions of Metal(loid)s in Agricultural Fields}

High As concentrations in the soil may be dangerous if growing plants are able to extract and accumulate it in the biomass. Arsenic accumulated in alfalfa leaf tissues, for example, can be toxic for cattle (Mandal, 2017) and if accumulated in vegetable leaves may be translocated to the edible parts of the plant (Vithanage et al., 2012). However, plants must also uptake nutrients from the soil. The bioavailability of metal(loid)s refers to water-soluble and exchangeable fractions. These fractions can be mobilized easily and taken up by plant roots (Intawongse \& Dean, 2006; Peralta-Videa et al., 2009).

The descriptive statistics (mean, standard deviation, minimum and maximum) for total, water-soluble, and exchangeable As analyzed in randomly collected field samples from the A and $\mathrm{V}$ fields are shown in Table 4. The mean value of total As in fields $\mathrm{A}$ and $\mathrm{V}$ exceeds the RSL value of $7.07 \mathrm{mg} \mathrm{kg}^{-1}$. However, the water-soluble and exchangeable fractions are significantly lower; in fact, they are less than $3 \%$ of the total As concentration.

The exchangeable and water-soluble As concentrations are so low, compared to the total amount of As, that they would probably not accumulate in the plant tissue. Arsenic may also be bound to carbonates, organic matter, or silicates present in the soil matrix and may be transformed to water-soluble or exchangeable forms under favorable physicochemical conditions (Brallier et al., 1996). The results presented by Matthews et al. (2020) to assess the safety of edible produce (corn, cucurbits) bolster our finding. They found that the produce harvested for consumption from agricultural fields irrigated by the Animas River does not accumulate As beyond the WHO/FAO standards.

The water-soluble and exchangeable fractions of As compared between the two fields show a similar trend. The exchangeable As fraction is an order of magnitude higher than water-soluble fractions in both fields. The average water-soluble and exchangeable fractions are higher in field A than field V. This may be due to the alfalfa growing in field A that provides more organic matter than in the vegetable field V. Organic matter has been shown to complex metals and keep them in solution (Essington, 2015).

The bioavailable or plant available metal(loid) fractions depend on many factors including soil $\mathrm{pH}$, 
Table 4 Total, water-soluble, and exchangeable arsenic concentrations $\left(\mathrm{mg} \mathrm{kg}^{-1}\right)$ in sequentially extracted soil samples in field A ( $n=7$ samples) irrigated by Animas River water and field V ( $n=7$ samples) irrigated by San Juan River water

\begin{tabular}{lllll}
\hline Field & \multicolumn{2}{c}{$\begin{array}{c}\text { Total As* } \\
\left(\mathrm{mg} \mathrm{kg}^{-1}\right)\end{array}$} & Water-soluble As & Exchangeable As \\
\hline A & Mean & 7.35 & 0.054 & 0.224 \\
& SD** & 1.09 & 0.013 & 0.107 \\
& Min & 5.62 & 0.032 & 0.144 \\
& Max & 8.64 & 0.074 & 0.450 \\
V & Mean & 11.42 & 0.018 & 0.176 \\
& SD & 1.74 & 0.002 & 0.037 \\
& Min & 9.65 & 0.014 & 0.135 \\
& Max & 14.79 & 0.021 & 0.248 \\
\hline
\end{tabular}

*All samples analyzed by inductively coupled plasma-mass spectrometry (ICP-MS).

**Standard deviation (SD), minimum (Min), and maximum (Max).

organic matter, solution composition, and soil texture (Caporale \& Violante, 2016). The soils in both fields are calcareous and range in $\mathrm{pH}$ from neutral to moderately alkaline. Soils containing calcium carbonate may retain As on calcite between $\mathrm{pH} 7$ and 9 (Sadiq, 1997). The two oxidation states of As behave differently in soil; arsenite $\left(\mathrm{As}^{3+}\right)$ is mobile and toxic while arsenate $\left(\mathrm{As}^{5+}\right)$ is more likely to be adsorbed by soil. Goldberg and Glaubig (1988) found that sorption of arsenate increased on calcite as $\mathrm{pH}$ increased from 7 to 12 . Tetrahedral arsenate ions $\left(\mathrm{As}^{5+}\right)$ are incorporated into the calcite crystals present in soils by substituting the planar carbonates $\left(\mathrm{CO}_{3}{ }^{2-}\right)$ (Alexandratos et al., 2007).

This study was a preliminary analysis of the bioavailable fractions of As for plant uptake. It aims to serve as the basis for expanding research across the agricultural fields irrigated by Animas and San Juan Rivers for other toxic metals like $\mathrm{Pb}$, chromium $(\mathrm{Cr})$, and aluminum (Al). The analytical component of this research focused on water-soluble and exchangeable fractions of As; however, it can further be expanded to understand the oxidizable and residual fractions in soils. Other reagents like weak acid extraction using diethylenetriaminepentaacetic acid (DTPA) can also be used to analyze the labile pool or plant available fractions of toxic metals in the agricultural soils contaminated by acid mine drainage.

\section{Conclusions}

This study monitored the metal(loid)s of concern that may have moved downstream with the Animas and San Juan River water as a result of the Gold King Mine spill and also due to legacy mining activities. Portable X-ray fluorescence (PXRF) spectrometry was used for rapid and in situ measurements of total concentrations of metal(loid)s in soils of two agricultural fields irrigated by the river water. The PXRF analysis was validated by correlating the measured total concentrations for representative samples using the ICP technique in the laboratory. Strong correlation coefficients were observed ranging from 0.80 (for $\mathrm{Mn}$ ) to 0.96 (for Ca). All of the metal(loid)s except arsenic (As) were below the residential soil screening levels set by EPA or NMED in two sampled agricultural fields. Spatial analysis was performed using ordinary kriging interpolation technique derived from leave-one-out cross validation by using the lowest root mean square error (RMSE) compared between spherical, circular, and exponential models. The interpolated PXRF maps of each field showed differences in total As distribution and indicated regions or locations in the fields where As concentration exceeded $7.07 \mathrm{mg} \mathrm{kg}^{-1}$. The water-soluble and exchangeable fractions, comprising the plant available forms of As, were measured and compared to the total As concentrations. These bioavailable fractions of water-soluble and exchangeable As were less than 1 and 3\%, respectively, of the total As concentration and therefore are thought to pose little threat of plant accumulation.

Supplementary Information The online version contains supplementary material available at https://doi.org/10.1007/ s11270-021-05249-2.

Acknowledgements The authors sincerely thank the farmers in the region for allowing us to conduct research in their fields. The authors would like to thank USDA-National Institute of Food and Agriculture for salary support through various Hatch grants and New Mexico State University-Agriculture Science Center at Farmington (NM) for providing resources during fieldwork. The authors are thankful to Catie Chavez, Jaime Grijalva, Evan Pointer, Roya Ghorbani, Barbara Hunter, and Brandon Francis for assistance with laboratory analysis and field work.

Funding Funding for this project was granted by New Mexico Water Resources Research Institute 2018 Student Grant (NMWRRI-SG-18). 
Data availability Not applicable.

Code availability Not applicable.

\section{Declarations}

Competing interests The authors declare no competing interests.

Open Access This article is licensed under a Creative Commons Attribution 4.0 International License, which permits use, sharing, adaptation, distribution and reproduction in any medium or format, as long as you give appropriate credit to the original author(s) and the source, provide a link to the Creative Commons licence, and indicate if changes were made. The images or other third party material in this article are included in the article's Creative Commons licence, unless indicated otherwise in a credit line to the material. If material is not included in the article's Creative Commons licence and your intended use is not permitted by statutory regulation or exceeds the permitted use, you will need to obtain permission directly from the copyright holder. To view a copy of this licence, visit http://creativecommons.org/licenses/by/4.0/.

\section{References}

Al Maliki, A., Al-lami, A. K., Hussain, H. M., \& Al-Ansari, N. (2017). Comparison between inductively coupled plasma and $\mathrm{X}$-ray fluorescence performance for $\mathrm{Pb}$ analysis in environmental soil samples. Environmental Earth Sciences, 76(12), 433.

Allan, M.J. (2018). Understanding soil spatial and temporal variability for forage corn production and hydrological modeling within New Mexico (Masters Thesis, New Mexico State University).

Alexandratos, V. G., Elzinga, E. J., \& Reeder, R. J. (2007). Arsenate uptake by calcite: Macroscopic and spectroscopic characterization of adsorption and incorporation mechanisms. Geochimica Et Cosmochimica Acta, 71(17), 4172-4187.

Allison, L. E., \& Richards, L. A. (1954). Diagnosis and improvement of saline and alkali soils (No. 60). Soil and Water Conservative Research Branch, Agricultural Research Service, US Department of Agriculture.

Alloway, B. J. (Ed.). (2012). Heavy metals in soils: Trace metals and metalloids in soils and their bioavailability (Vol. 22). Springer Science and Business Media.

Arcon, I., van Elteren, J. T., Glass, H. J., Kodre, A., \& Šlejkovec, Z. (2005). EXAFS and XANES study of arsenic in contaminated soil. X-Ray Spectrometry: An International Journal, 34(5), 435-438.

Bettinelli, M., Beone, G. M., Spezia, S., \& Baffi, C. (2000). Determination of heavy metals in soils and sediments by microwave-assisted digestion and inductively coupled plasma optical emission spectrometry analysis. Analytica Chimica Acta, 424(2), 289-296.

Brallier, S., Harrison, R. B., Henry, C. L., \& Dongsen, X. (1996). Liming effects on availability of $\mathrm{Cd}, \mathrm{Cu}, \mathrm{Ni}$ and $\mathrm{Zn}$ in a soil amended with sewage sludge 16 years previously. Water, Air, and Soil Pollution, 86(1-4), 195-206.

Briggs, J. C., \& Ficke, J. F. (1977). Quality of rivers of the United States, 1975 water year; based on the National Stream Quality Accounting Network (NASQAN) (No. 78-200). US Geological Survey.

Bureau of Land Management, (2016). Concentration of Abandoned Mine Lands Portal https://www.abandonedmines. gov/ Accessed July 15, 2019.

Cambardella, C. A., Moorman, T. B., Novak, J. M., Parkin, T. B., Karlen, D. L., Turco, R. F., \& Konopka, A. E. (1994). Field-scale variability of soil properties in central Iowa soils. Soil Science Society of America Journal, 58(5), 1501-1511.

Caporale, A. G., \& Violante, A. (2016). Chemical processes affecting the mobility of heavy metals and metalloids in soil environments. Current Pollution Reports, 2(1), 15-27.

Casadevall, T., \& Ohmoto, H. (1977). Sunnyside Mine, Eureka mining district, San Juan County, Colorado; geochemistry of gold and base metal ore deposition in a volcanic environment. Economic Geology, 72(7), 1285-1320.

Chan, Y. H. (2003). Biostatistics 104: Correlational analysis. Singapore Med J, 44(12), 614-619.

Chakraborty, S., Man, T., Paulette, L., Deb, S., Li, B., Weindorf, D. C., \& Frazier, M. (2017). Rapid assessment of smelter/mining soil contamination via portable X-ray fluorescence spectrometry and indicator kriging. Geoderma, $306,108-119$.

Church, S. E., Owen, J. R., Von Guerard, P., Verplanck, P. L., Kimball, B. A., \& Yager, D. B. (2007). The effects of acidic mine drainage from historical mines in the Animas River watershed, San Juan County, Colorado-What is being done and what can be done to improve water quality. Reviews in Engineering Geology, 17, 47-83.

Cihacek, L. J. (1983). Interpreting soil analysis. Cooperative extension service guide a-126. Las Cruces: New Mexico State University, Publication Office, Las Cruces, New Mexico.

Essington, M. E. (2015). Soil and water chemistry: An integrative approach. CRC press.

Fullen, S. (2017). Arsenic and lead total concentration in Aztec, NM Irrigation Ditch Sediments-A result of legacy mining (Master's thesis). New Mexico State University.

Flynn, R. (2012). Appropriate analyses for New Mexico soils. Guide A-146, Las Cruces, NM.

Gavlak, R., Horneck, D., Miller, R. O., \& Kotuby-Amacher, J. (2003). Soil, plant and water reference methods for the western region. WCC-103 Publication, Fort Collins, Colorado.

Goldberg, S., \& Glaubig, R. A. (1988). Anion sorption on a calcareous, montmorillonitic soil-arsenic. Soil Science Society of America Journal, 52(5), 1297-1300.

Goss, C. (2016, March 24). Red and Bonita Mine bulkhead closure evaluation; DandA Job No. CG-0628.001.00 [Letter written March 24, 2016 to Mr. Elliott Petri]. Retrieved from https://semspub.epa.gov/work/08/1771093.pdf

Intawongse, M., \& Dean, J. R. (2006). Uptake of heavy metals by vegetable plants grown on contaminated soil and their bioavailability in the human gastrointestinal tract. Food Additives and Contaminants, 23(1), 36-48.

Jha, G., Mukhopadhyay, S., Ulery, A. L., Lombard, K., Chakraborty, S., Weindorf, D. C., VanLeeuwen, D., \& 
Brungard, C. (2021a). Agricultural soils of the animas river watershed after the Gold King Mine spill: An elemental spatiotemporal analysis via portable x-ray fluorescence spectroscopy. Journal of Environmental Quality, 50(3), 730-743. https://doi.org/10.1002/jeq2.20209

Jha, G., Sihi, D., Dari, B., Kaur, H., Nocco, M.A., Ulery, A. \& Lombard, K. (2021b). Rapid and inexpensive assessment of soil total iron using Nix Pro color sensor. Agricultural \& Environmental Letters 00:;1-6. https://doi.org/10.1002/ael2.20050

Kabir, M. S., Salam, M. A., Paul, D. N. R., Hossain, M. I., Rahman, N. M. F., Aziz, A., \& Latif, M. A. (2016). Spatial variation of arsenic in soil, irrigation water, and plant parts: a microlevel study. The Scientific World Journal, 2016.

Kalra, Y. P. (1998). Handbook of reference methods for plant analysis. CRC Press.

Kumar, S. N., Mishra, B. B., Kumar, S., \& Mandal, J. (2021). Organo-arsenic complexation studies explaining the reduction of uptake of arsenic in wheat grown with contaminated irrigation water and organic amendments. Water, Air, and Soil Pollution, 232(3), 1-10.

Luedke, R. G. \& W. S. Burbank (1999). Geologic map of the Silverton and Howardsville quadrangles, southwestern Colorado. U. S. G. Survey

Li, H., Shi, A., Li, M., \& Zhang, X. (2013). Effect of pH, temperature, dissolved oxygen, and flow rate of overlying water on heavy metals release from storm sewer sediments. Journal of Chemistry, 2013.

Li, J., \& Heap, A. D. (2011). A review of comparative studies of spatial interpolation methods in environmental sciences: Performance and impact factors. Ecological Informatics, 6(3-4), 228-241.

Ludwick, A. E. \& J. O. R. (1974). Guide to fertilizer recommendations in Colorado. Colorado State University, Fort Collins, Colorado.

Mandal, J., Golui, D., \& Datta, S. P. (2019). Assessing equilibria of organo-arsenic complexes and predicting uptake of arsenic by wheat grain from organic matter amended soils. Chemosphere, 234, 419-426.

Mandal, P. (2017). An insight of environmental contamination of arsenic on animal health. Emerging Contaminants, $3(1), 17-22$.

Matthews, A. N., Rogus, S., Jha, G., Ulery, A., Delgado, E., Lombard, K., Hunter, B., \& Francis, B. (2020). Heavy metal content of produce grown in San Juan County (New Mexico, USA). Journal of Environmental Science and Health, Part B, 55(10), 889-897.

Nelson, D. W., \& Sommers, L. E. (1996). Total carbon, organic carbon, and organic matter. In Methods of soil analysis. Part 3. Chemical methods, ed. D. L. Sparks. Soil Science Society of America, 961-1010.

Ohmer, M., Liesch, T., Goeppert, N., \& Goldscheider, N. (2017). On the optimal selection of interpolation methods for groundwater contouring: An example of propagation of uncertainty regarding inter-aquifer exchange. Advances in Water Resources, 109, 121-132.

Ogundiran, M. B., \& Osibanjo, O. (2009). Mobility and speciation of heavy metals in soils impacted by hazardous waste. Chemical Speciation and Bioavailability, 21(2), 59-69.

Olsen, S. R., Cole, C. V., Watanabe, F. S., \& Dean, L. A. (1954). Estimation of available phosphorus in soils by extraction with sodium bicarbonate. USDA Circular No. 939, U.S. Gov. Print. Office, Washington, D.C.

Peinado, F. M., Ruano, S. M., González, M. B., \& Molina, C. E. (2010). A rapid field procedure for screening trace elements in polluted soil using portable X-ray fluorescence (PXRF). Geoderma, 159(1-2), 76-82.

Peralta-Videa, J. R., Lopez, M. L., Narayan, M., Saupe, G., \& Gardea-Torresdey, J. (2009). The biochemistry of environmental heavy metal uptake by plants: Implications for the food chain. The International Journal of Biochemistry and Cell Biology, 41(8-9), 1665-1677.

Rose, A. W. \& Cravotta C. A. I. (1998). Geochemistry of coal mine drainage. Coal mine drainage prediction and pollution prevention. Harrisburg, Pennsylvania, Pennsylvania Department of Environmental Protection: 1-1 to 1-22.

Rodriguez-Freire, L., Avasarala, S., Ali, A. M. S., Agnew, D., Hoover, J. H., Artyushkova, K., \& Brearley, A. J. (2016). Post Gold King Mine spill investigation of metal stability in water and sediments of the Animas River watershed. Environmental Science and Technology, 50(21), 11539-11548.

Rouillon, M., \& Taylor, M. P. (2016). Can field portable $\mathrm{X}$-ray fluorescence ( $\mathrm{pXRF}$ ) produce high quality data for application in environmental contamination research? Environmental Pollution, 214, 255-264.

Sadiq, M. (1997). Arsenic chemistry in soils: An overview of thermodynamic predictions and field observations. Water, Air, and Soil Pollution, 93(1-4), 117-136.

Schemel, L. E., \& Cox, M. H. (2005). Descriptions of the Animas River-Cement Creek confluence and mixing zone near Silverton, Colorado, during the late summers of 1996-1997 (No. Open-file-2005-1064). U.S. Geological Survey Washington DC.

Shackley, M. S. (2012). Portable X-ray fluorescence spectrometry (pXRF): The good, the bad, and the ugly. Archaeology Southwest Magazine, 26(2), 1-8.

Smeal, D., O’Neill, M. K., Owen, C. K., West, M. M., Allen, S. C., \& Arnold, R. N. (2014). Forty-three years (19692011) of climatological data: NMSU's Agricultural Science Center at Farmington. NM State University, Cooperative Extension Service.

Sparks, D. L. (2003). Environmental soil chemistry. Academic Press, San Diego, CA. Environmental soil chemistry. 2nd ed., pg. 45-209, Academic Press, San Diego, CA.

Tessier, A., Campbell, P. G., \& Bisson, M. (1979). Sequential extraction procedure for the speciation of particulate trace metals. Analytical Chemistry, 51(7), 844-851.

US Department of Interior (2015). Technical Evaluation of the Gold Kind Mine Incident. Retrieved from- https://www. usbr.gov/docs/goldkingminereport.pdf Accessed July 15, 2019.

US EPA (2007). Field portable X-ray fluorescence spectrometry for the determination of elemental concentrations in soil and sediment. Retrieved from https://www.epa. gov/sites/production/files/2015-12/documents/6200.pdf. SW-846 (February 2007 update)

US EPA (2016). Geochemical Considerations Regarding the Gold King Mine Release. Retrieved from-https://www.resea rchgate.net/publication/328858121_Geochemical_Considerations_ 
Regarding_the_Gold_King_Mine_Release Accessed July 15, 2019.

Varnes, D. J. (1963). Geology and ore deposits of the South Silverton mining area, San Juan County, Colorado (No. 378-A). US Government Printing Office.

Vithanage, M., Dabrowska, B. B., Mukherjee, A. B., Sandhi, A., \& Bhattacharya, P. (2012). Arsenic uptake by plants and possible phytoremediation applications: A brief overview. Environmental Chemistry Letters, 10(3), 217-224.

Webb, G. I., Sammut, C., \& Perlich, C. (2010). Leave-one-out cross-validation. Encyclopedia of Machine Learning (pp. 600-601). Springer.

Weindorf, D. C., Paulette, L., \& Man, T. (2013). In-situ assessment of metal contamination via portable X-ray fluorescence spectroscopy: Zlatna, Romania. Environmental Pollution, 182, 92-100.

Weindorf, D. C., Bakr, N., \& Zhu, Y. (2014). Advances in portable X-ray fluorescence (PXRF) for environmental, pedological, and agronomic applications. In Advances in Agronomy (Vol. 128, pp. 1-45). Academic Press.

Weindorf, D. C., \& Chakraborty, S. (2016). Portable X-ray fluorescence spectrometry analysis of soils. In D. Hirmas (Ed.), Methods of soil analysis (pp. 1-8). Soil Science Society of America.

Wirt, L., Vincent, K. R., Verplanck, P. L., Yager, D. B., Church, S. E., \& Fey, D. L. (2007). Geochemical and hydrologic processes controlling formation of ferricrete. In S. E. Church, P. Von Guerard, and S.E. Finger (Eds.), Integrated investigations of environmental effects of historical mining in the Animas River watershed, San Juan County, Colorado (pp. 823 - 835) US Geological Survey Professional Paper, (Vol. 1651).
Xiaopeng, Q. I., Liang, W., Barker, L., Lekiachvili, A., \& Xingyou, Z. (2012). Comparison of ArcGIS and SAS geostatistical analyst to estimate population-weighted monthly temperature for US counties. Journal of Resources and Ecology, 3(3), 220.

Yager, D. B., Church, S. E., Verplanck, P. L., \& Wirt, L. (2003). Ferricrete, manganocrete, and bog iron occurrences with selected sedge bogs and active iron bogs and springs in the upper Animas River watershed, San Juan County, Colorado. U.S. Geological Survey Miscellaneous Field Studies Map (No. 2406). Retrieved from: https://doi. org/10.3133/mf2406 (Accessed 08/09/2019)

Yager, D.B., \& Bove, D.J. (2007). Geologic framework. In S. E. Church, P. Von Guerard, and S.E. Finger (Eds.), Integrated investigations of environmental effects of historical mining in the Animas River watershed, San Juan County, Colorado (pp. 823 - 835). US Geological Survey Professional Paper, (Vol. 1651). Retrieved from: https://pubs. usgs.gov/pp/1651/ (Accessed 10/17/2019)

Zimmerman, A. J., \& Weindorf, D. C. (2010). Heavy metal and trace metal analysis in soil by sequential extraction: a review of procedures. International Journal of Analytical Chemistry, vol. 2010, Article ID 387803. Retrieved from:https://doi.org/10.1155/2010/387803(Accessed10/ 17/2019)

Publisher's Note Springer Nature remains neutral with regard to jurisdictional claims in published maps and institutional affiliations. 